\title{
White Pine Blister Rust in British Columbia II. Can Stands be Hazard Rated?
}

by

\author{
R.S. Hunt
}

\section{Abstract}

Twelve to 30 -year-old western white pine (Pinus monticola Dougl.) in 23 stands in British Columbia were surveyed for blister rust (Cronartium ribicola J.C. Fisch. ex Rab.) cankers. Canker length, mid-point diameter, and height above ground were measured. The number of cankers per tree tended to increase with tree diameter, was variable within stands, and on 15 to $20 \mathrm{~cm}$ diameter trees ranged from a mean of one to 14 per stand and the overall mean was four cankers per tree. Large branches bore longer cankers and tended to be higher in the tree than small branches which bore short cankers. Incidence of cankers above $2.5 \mathrm{~m}$ tended to increase with increasing slope and they were on the side of the tree subject to evening breezes. Based on Idaho standards all sites in British Columbia were rated as low hazard, but trees growing on slopes had a higher risk than those on flat sites.

Key words: Cronartium, Pinus monticola, hazard rating

\section{Résumé}

Les chancres causés par la rouille vésiculeuse du pin blanc (Cronartium ribicola J.C. Fisch. ex Rab.) ont été l'objet d'un relevé sur des pins argentés (Pinus monticola Dougl.) de 12 à 30 ans dans 23 peuplements de la Colombie-Britannique. La longueur et le diamètre médian des chancres ont été mesurés de même que leur hauteur par rapport au sol. Le nombre de chancres sur l'arbre tend à augmenter avec le diamètre de l'arbre et il varie à l'intérieur des peuplements; sur les arbres de 15 à $20 \mathrm{~cm}$ de diamètre, il se situe en moyenne entre 1 et 14 par peuplement, pour une moyenne globale de 4 par arbre. Les grosses branches portent des chancres plus longs et tendent à être plus hautes dans l'arbre que les petites branches qui portent de petits chancres. L'incidence des chancres au-dessus de 2,5 $\mathrm{m}$ tend à augmenter avec la pente et les chancres se trouvent du côté exposé aux vents du soir. Tous les emplacements de la Columbie-Britannique sont classés dans la catégorie de risque peu élevé selon les critères de l'Idaho, mais les arbres se trouvant sur des terrains en pente sont plus exposés que les arbres poussant sur terrain plat.

Mots clés: Cronartium, Pinus monticola, évaluation du risque.

\section{Introduction}

White pine blister rust, Cronartium ribicola J.C. Fisch. ex Rab., is a destructive disease that has restricted white pine management. One approach to solving this problem is to use blister rust hazard zones (Van Arsdel 1961). Hazard, i.e. the likelihood of tree damage from stem cankers, increases with increasing canker incidence. For eastern white pine (Pinus strobus L.), canker incidence correlates with moisture and temperature conditions limiting infection and these are the criteria used to delineate hazard zones (Van Ardsel et al. 1956; Lavallee 1974). Development of hazard zones or a hazard rating system for British Columbia could aid in selection of desirable planting sites and permit managers to optimize the timing of thinning and harvesting operations.

In British Columbia, most western white pine ( $P$. monticola Dougl.) occur at 600 m elevation or higher in several biogeoclimatic zones (Krajina 1969). Early work in two representative

Canadian Forestry Service. Pacific Forest Reserch Centre. 506 West Burnside Road. Victoria. BC. V8Z 1 M5. western white pine stands in British Columbia suggested that they may have fewer cankers than those at sea level (Lachmund 1934) or those in Idaho (Childs and Kimmey 1938).

Although differences in canker incidence are important in formulating hazard ratings, additional factors also influence tree damage (Childs and Kimmey 1938). One stand factor, slope (Hunt 1982) and two pathogen factors, canker growth and mortality, are thought to be the most important. The objective of this study was to hazard rate stands by considering the influence of these factors along with canker incidence.

\section{Methods}

In each of 23 stands located throughout the range of western white pine in British Columbia about 80 trees were sampled by the methods, and in locations, described previously (Hunt 1982).

To determine canker incidence both living and dead $T$-cankers, (i.e. those which could become stem cankers and are within $60 \mathrm{~cm}$ of the stem; Childs and Kimmey 1938) were tallied. Additional T-canker data included mid-point diameter, length, height above ground, and condition, i.e. alive or dead 
and whether the branch was dead at the distal end. All the cankers on twenty, 15 to $20 \mathrm{~cm}$ dbh trees from a stand with a relatively high canker incidence were counted and it was found that $40 \%$ of all cankers were not T-cankers.

Annual longitudinal growth rate for those live cankers still confined to the branches was determined by dividing canker length by the canker age. The age of each canker was determined by counting back annual increments of branch growth, since nearly all cankers originate from spores infecting current year's needles (Slipp 1949). In seven additional stands, on slopes steeper than $50 \%$, the cardinal directional point was recorded for cankers greater than $2.5 \mathrm{~m}$ above the ground.

\section{Results}

In all 23 stands sampled, the mean number of T-cankers per tree was 1.1 (range of 0.4 to 4.0 ) (Fig. 1). The number of cankers increased with tree diameter, but the rate of increase tended to decrease with increasing diameter (Fig. 2). Fourteen stands had trees in the larger diameter classes, 11 to $20 \mathrm{~cm} \mathrm{dbh}$, and in these the mean number of T-cankers per tree was 2.1 (range of 0.7 to 8.1 ).

The annual growth rate of the pathogen, based on live cankers, increased with increasing midpoint diameter of the canker and varied among stands (Fig. 3). Also, the length of dead T-cankers increased with the host branch diameter (Fig. 4). Among the 10 stands for which there was enough data for a meaningful comparison, the length of T-cankers on branches 0 to $6 \mathrm{~mm}$ diameter was significantly different (Table 1). The pattern of significant differences $(P=.05)$ among stands was similar for other branch diameters. The correlation between growth rate (Fig. 3 ) and canker length (Table 1) was weak (Spearman's rank coefficient value 0.56 ; Zar 1974). In fact, the stand with the slowest canker growth rate had nearly the longest cankers (stand no. 13). Also, there was no apparent correlation between canker growth rate or total length to elevation or biogeoclimatic zone.

In branches higher than $1.25 \mathrm{~m}$ a greater percentage of large diameter branches $(>20 \mathrm{~mm})$ were found infected than small diameter $(<19 \mathrm{~mm}$ ) branches (Fig. 5). Most stands

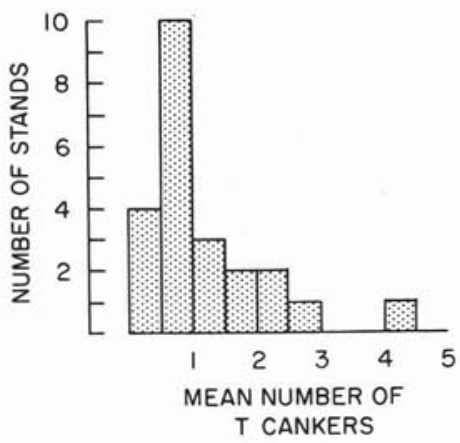

Figure 1. Distribution of T-cankers in all trees among 23 surveyed stands. investigated for cardinal direction of cankers in the crown had significantly more $(>.001$; Chi-square) cankers clustered on the side of the tree facing prevailing fall winds or the evening air drainage off adjacent mountains (Fig. 6).

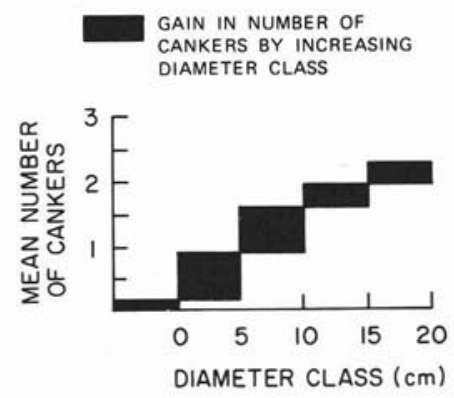

Figure 2. The relationship between number of cankers and diameter among 14 stands.

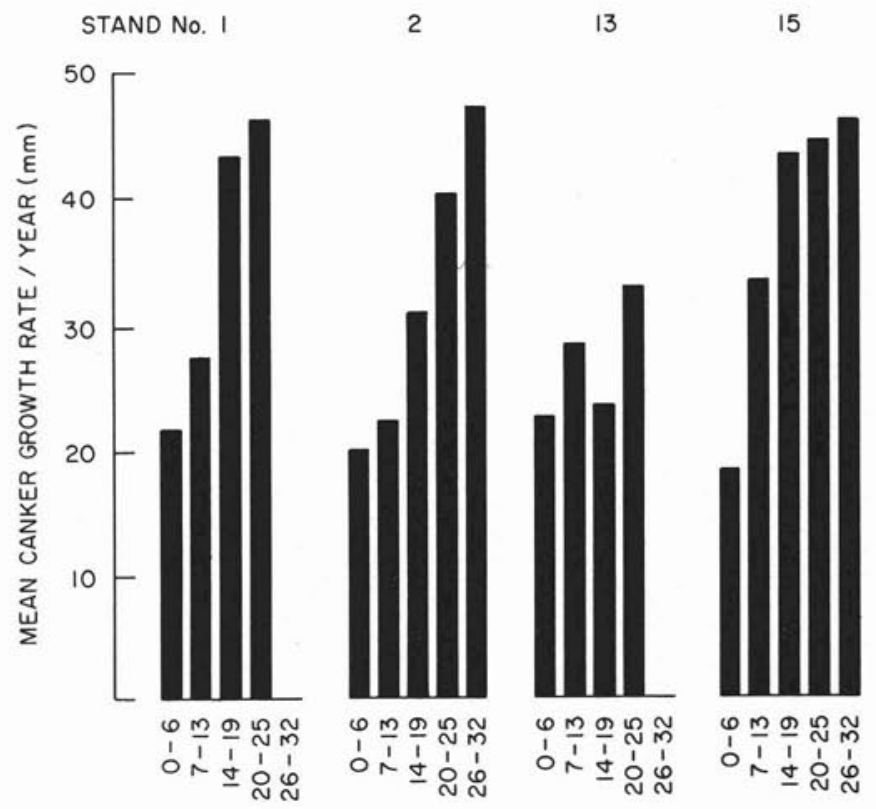

BRANCH DIAMETER CLASS $(\mathrm{mm})$

Figure 3. The relationship between canker growth rate and branch diameter class.

\begin{tabular}{|c|c|c|c|c|c|c|c|c|c|c|}
\hline Stand number & 15 & 2 & 14 & 12 & 17 & 7 & 16 & 5 & 13 & 1 \\
\hline $\begin{array}{l}\text { Mean length of dead } \\
\text { branch cankers }(\mathrm{cm})\end{array}$ & 11.4 & 11.6 & 13.5 & 15.0 & 19.3 & 19.6 & 20.3 & 23.5 & 23.6 & 25.1 \\
\hline
\end{tabular}

-Values underscored by the same line do not differ significantly, according to Duncan's multiple range test $(P=, 05)$. 


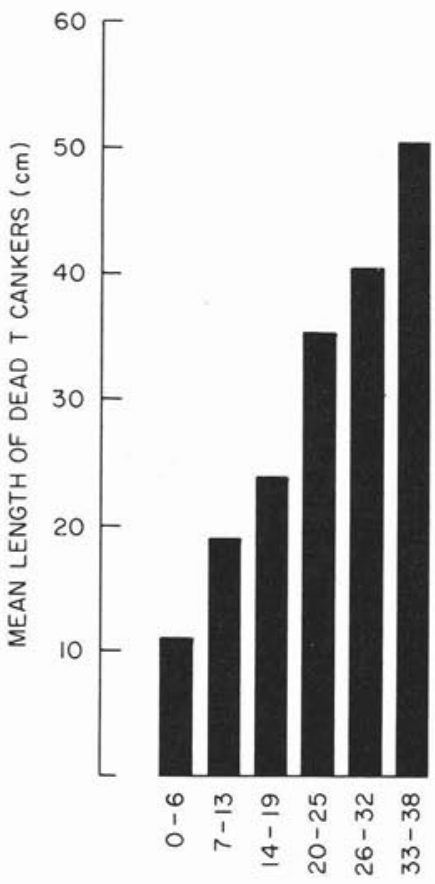

BRANCH DIAMETER

CLASS $(\mathrm{mm})$

Figure 4. The relationship between canker length and branch diameter class.

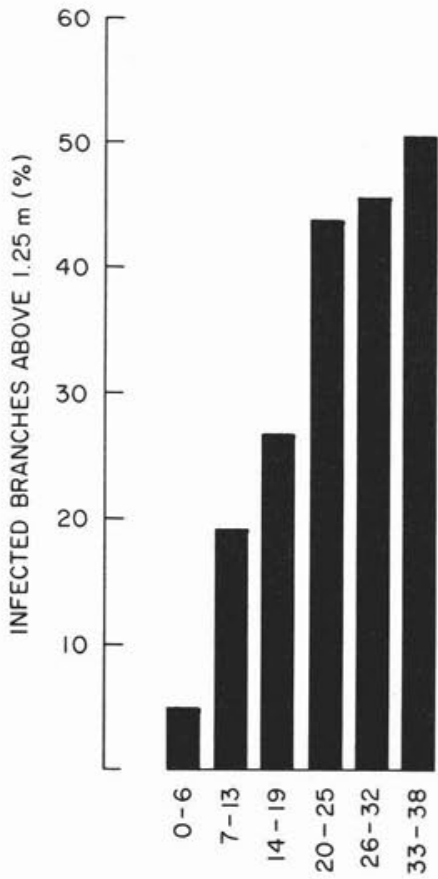

BRANCH DIAMETER CLASS ( $\mathrm{mm}$ )

Figure 5. Blister rust incidence on larger branches $(>20 \mathrm{~mm})$ higher than $1.25 \mathrm{~m}$ above ground (stand \#2).

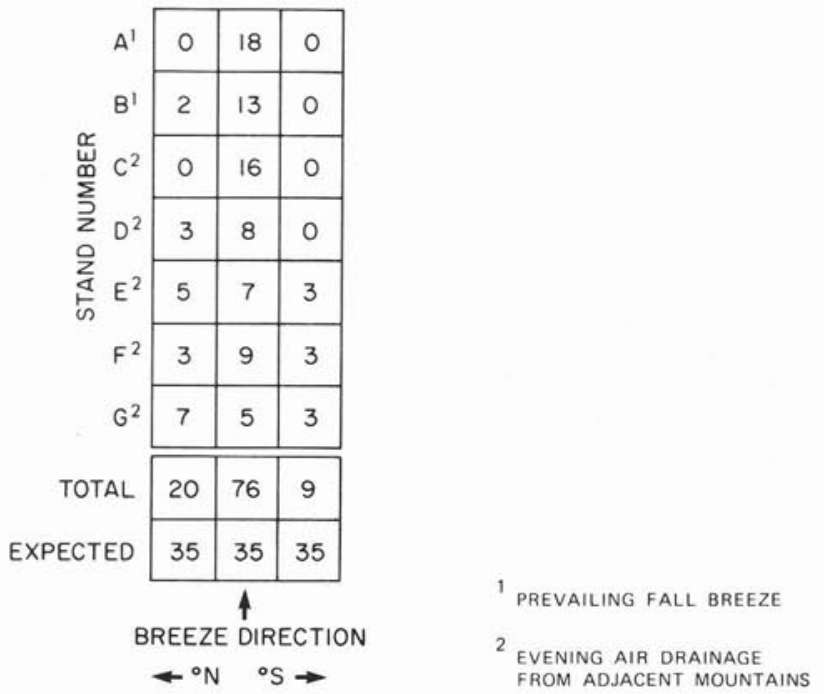

Figure 6. The number of car sers above $2.5 \mathrm{~m}$ and their association with fall evening breezes

\section{Discussion}

Idaho's infection incidence, ranges from a low of 10-20 cankers per tree to more than 150 cankers per tree (Hoff and McDonald 1980) with one representative area in north central Idaho yielding a mean of 40 cankers per tree in 1000 25-yearold trees (Martin 1979 and pers. comm.). However, in British Columbia the mean number of T-cankers in comparable trees (11 to $20 \mathrm{~cm}$ diameter) was 2.1 with a range of $0.7-8.1$, which, when adjusted upward by $40 \%$ to obtain the total number of branch cankers, gives a mean of 3.5 , with a range of 1.2-13.5 cankers per tree. Based on these data, British Columbia's western white pine sites apparently are very low hazard. However, the hazard is still much higher than for eastern white pine (Van Arsdel 1961; Lavallee 1974); hence many trees die from blister rust.

In British Columbia few stands have alternate hosts scattered among them (Buckland 1946. Hunt unpublished data), and in the Interior of British Columbia, Ribes lacustre (Pers.) Poir., the dominant alternate host is primarily concentrated along stream banks (Thomas and Roff 1947; Hopkins 1974). In Idaho one of the additional main alternate hosts is $R$. inerme Rydb. (Mielke et al. 1937) which is found scattered within the stands (Hitchcock et al. 1961). Also, R. inerme and some other Ribes spp. south of British Columbia are considered to be better hosts for $C$. ribicola than R. lacustre (Mielke et al. 1937; Kimmey 1938; Kimmey and Wagener 1961). Lack of these Ribes spp. likely contributes to a reduced rust spore density in British Columbia and results in a low canker incidence.

Buchanan (1938) suggested that a fast canker growth rate, such as may occur in areas where the growing season is longer, would mean more tree damage. However, long cankers, which are most likely to cause stem cankers and tree damage, may result from either a fast growth rate or long survival. Therefore, if canker incidence were similar among stands, a fast canker growth rate does not necessarily mean more damage since the mortality rate must also be considered. The length of a dead canker is attributable to its growth and length of survival. The length of dead cankers varied among stands (Table 1), and did not appear to correlate with site factors and only weakly with growth rate. Hence, the 
mortality rate of cankers influences tree damage and would add to the complexity of a hazard rating system based on relatively small differences in canker incidence among stands.

The data indicated that the annual growth rate of cankers increased with increasing branch diameter, as reported previously by Lachmund (1934) and Buchanan (1938). Dense vigorous stands favor production of small diameter branches, which are least likely to have long cankers that successfully reach the stem (Fig. 3 and 4 ), and which favor early natural pruning of the hazardous lower branches (Hunt 1982). Also, the denser a stand, the more likely that $C$. ribicola spores wil be filtered out by the foliage nearest the inoculum source (Kimmey and Wagener 1961). Open grown stands would permit more movement of $C$. ribicola spores, and the trees would have thick persistent branches which favor successfu stem infection by $C$. ribicola.

Wind patterns may explain why stands on slopes tended to have infections at a particular cardinal directional point since Van Arsdel (1967) found in the east that there were more infections in trees subject to evening breezes. Also, more crown exposure and more breezy conditions may explain why cankers were found further up trees on slopes (Hunt 1982) than on flat sites. Trees on all sites may be severely damaged when young (Hunt 1982) but those on slopes will probably be subject to some crown infection lasting throughout a rotation. Also, threatening cankers further up the tree are more likely to become stem infections than those lower down, because larger branches are infected (Fig. 5). The larger branches favor more rapid $C$. ribicola growth (Fig. 3 ) and canker survival (Fig. 4). Slope, therefore, apparently contributes to the greatest difference in hazard among British Columbia's white pine stands.

Trees of lowest hazard are vigorous in dense stands on flat sites, and trees of highest hazard are open grown on slopes. Minor variation in hazard may be caused by proximity to Ribes spp. especially near streams, and differential growth and mortality rates of $C$. ribicola cankers. Additional microsite factors may cause differences in canker incidence within stands.

Early thinning in western white pine stands will favor retention and increased diameter growth of lower branches, and thus increase the likelihood of $C$. ribicola stem infections. To avoid this situation, lower branches should be removed during thinning (Hunt 1982).

Separating candidate trees resistant to blister rust from those that escape infection is based upon candidate trees with considerably fewer cankers than the stand average (Hoff and McDonald 1980). Since the canker incidence is low in British Columbia, escapes are relatively common, thus making it difficult to determine which trees may be resistant.

\section{Conclusions}

Damage to western white pine by blister rust increases with increasing canker incidence, a fast canker growth rate and longevity of cankers. In general, throughout British Columbia, these factors appear to act independently and were not correlated with site factors. From the relatively small differences found in canker incidence, prediction of different levels of hazard among stands does not appear practical because differences could be obscured by growth and mortality rates of the cankers. Since canker incidence varies over a low range, the stands can be hazard rated as "low". This is useful for developing future management recommendations; however, selection of genetically resistant trees would be difficult because many trees may escape infection without being genetically resistant.

The greatest difference in hazard was found between stands on slopes and those on flats. Trees in all stands were attacked when young, but trees on slopes would be continuously infected throughout a rotation.

\section{References}

Buchanan, T.S. 1938. Annual growth rate of Cronartium ribicola cankers on branches of Pinus monticola in northern Idaho. Phytopathology 28: 634-641.

Buckland, D.C. 1946. Interim report on the effect of blister rust damage to the management of western white pine in the Upper Arrow Forest. Can. Dep. Agr., Lab. For. Path., Victoria, BC. (mimeograph) $37 \mathrm{p}$.

Childs, T.W. and J.W. Kimmey. 1938. Studies on probable damage by blister rust in some representative stands of young western white pine. J. Agr. Res. 57: 557-568

Hitchcock, C.L., A. Cronquist, M. Ownbey and J.W. Thompson. 1961. Vascular Plants of the Pacific Northwest, Part 3. Univ. of Wash. press

Hoff, R.J. and G.I. McDonald. 1980. Improving rust-resistant strains of inland western white pine. USDA For. Serv. Res. Pap. INT$245,13 p$

Hopkins, J.C. 1974. Blister rust in BC: a progress report. Pac. For. Res. Cent., Victoria, BC, File Rep. PC-13-114, 28 p.

Hunt, R.S. 1982. White pine blister rust in British Columbia I. The possibilities of control by branch removal. For. Chron. 58: $136-138$

Kimmey, J.W. 1938. Susceptibility of Ribes to Cronartium ribicola in the west. J. For. 36: 312-320

Kimmey, J.W. and W.W. Wagener. 1961. Spread of white pine blister rust from ribes to sugar pine in California and Oregon. USDA For. Serv. Tech. Bull. 1251, $71 p$

Krajina, V.J. 1969. Ecology of forest trees in British Columbia. Ecol. West. N. Am. 2: 1-147.

Lachmund, H.G. 1934. Growth and injurious effects of Cronartium ribicola cankers on Pinus monticola. J. Agr. Res. 48: 475-503.

Lavallee, A. 1974. Une revaluation de la situation concernant la rouille vesiculeuse du pin blanc au Québec. For. Chron. 50: 228-232.

Martin, N.E. 1979. Pruning - an approach to management of blister rust. 27th Annual West. Int. For. Dis. Work Conf. 55-58, (cited with permission).

Mielke, J.L., T.W. Childs, and H.G. Lachmund. 1937. Susceptibility to Cronartium ribicola of the four principal Ribes species found within the commercial range of Pinus monticola. J. Agr. Res. 55: 317-346.

Slipp, A.W. 1949. Blister rust project - canker development following artificial inoculations. Univ. of Idaho Prog. Rep. (cited with permission)

Thomas, G.P. and J.W. Roff. 1947. Summary reports - white pine blister rust 1947 survey. Pac. For. Res. Cent., Victoria, BC. File PC-13-114.

Van Arsdel, E.P. 1961. Growing white pine in the Lake States to avoid blister rust. USDA For. Serv. Stat. Pap. 92, 11 p.

Van Arsdel, E.P. 1967. The nocturnal diffusion and transport of spores. Phytopathology 57: 1221-1229

Van Arsdel, E.P., A.J. Riker and R.F. Patton. 1956. The effects of temperature on the spread of white pine blister rust. Phytopathology 46: 307-318.

Zar, J.H. 1974. Biostatistical analysis. Prentice-Hall Inc., Englewood Cliffs, NJ 